Full-length article

\title{
Pharmacokinetics of His-tag recombinant human endostatin in Rhesus monkeys ${ }^{1}$
}

Hai-feng SONG ${ }^{2}$, Xiu-wen LIU, Hai-ning ZHANG, Bao-zhen ZHU, Shou-jun YUAN, Shang-yi LIU, Zhong-ming TANG

Department of Pharmacology and Toxicology, Beijing Institute of Radiation Medicine, Beijing 100850, China

\section{Key words}

endostatin; pharmacokinetics; Macaca mulatta; immunoenzyme techniques

\footnotetext{
${ }^{1}$ Project supported by the National Natural Science Foundation of China, № 39930180 .

${ }^{2}$ Correspondence to Assoc Prof Hai-feng SONG.

Phn 86-10-6693-1230. Fax 86-10-6693-1230.

Emailsonghf@nic.bmi.ac.cn
}

Received 2004-05-12

Accepted 2004-08-03

doi: 10.1111/j.1745-7254.2005.00009.x

\begin{abstract}
Aim: To study the pharmacokinetics and accumulation of an Escherichia coliexpressed His-tag fused recombinant human endostatin (rh-endostatin) in Rhesus monkeys. Methods: Rh-endostatin was iv or sc injected in Rhesus monkeys, and the rh-endostatin concentration in serum samples was determined by an enzyme immunoassay (EIA) method. The serum drug concentration-time data were analyzed by compartmental analysis using the practical pharmacokinetic program 3p97.

Results: Following iv administration at a dose rate of $1.5,4.5$, and $13.5 \mathrm{mg} / \mathrm{kg}$ in rhesus monkeys, the concentration-time curves of rh-endostatin were best fitted to a three-compartment open model. $\mathrm{AUC}_{(0-\infty)}$ linearly increased with dose, while $\mathrm{Cl}_{\mathrm{s}}$ exhibited no significant difference among different dose groups. The terminal half-lives $\left(\lambda_{3}\right)$ were $8 \pm 8,3.1 \pm 1.4$, and $20 \pm 14 \mathrm{~h}$, respectively. After sc administration at a dose rate of $1.5 \mathrm{mg} / \mathrm{kg}$, the concentration-time curve was best fitted to a two-compartment open model, with a terminal half-life $\left(T_{1 / 2 \beta}\right)$ of $8 \pm 3 \mathrm{~h}$. Bioavailability following sc injection was approximately $70 \% \pm 3 \%$. After consecutive iv injection of rh-endostatin at a dose rate of $1.5 \mathrm{mg} \cdot \mathrm{kg}^{-1} \cdot \mathrm{d}^{-1}$ for $7 \mathrm{~d}$, the $\mathrm{AUC}_{(0-24 \mathrm{~h})}$ substantially increased from $22 \pm 13 \mathrm{mg} \cdot \mathrm{h} \cdot \mathrm{L}^{-1}(\mathrm{~d} 1)$ to $50 \pm 29 \mathrm{mg} \cdot \mathrm{h} \cdot \mathrm{L}^{-1}(\mathrm{~d}$ $7)$, with an accumulation factor of $2.3 \pm 0.6(P<0.05)$. Conclusion: The pharmacokinetic behavior of rh-endostatin in Rhesus monkeys complies with linear kinetics within the examined dose range. It tends to be accumulated in bodies after repeated administration at a dose level of $1.5 \mathrm{mg} \cdot \mathrm{kg}^{-1} \cdot \mathrm{d}^{-1}$ for more than 7 consecutive days.
\end{abstract}

\section{Introduction}

Endostatin, which contains 178 amino acid residues, is a $20 \mathrm{kDa}$ COOH-terminal fragment of collagen XVIII ${ }^{[1]}$. It was firstly identified as an angiogenesis inhibitor in 1997. Endostatin specifically inhibits endothelial proliferation and potently inhibits angiogenesis and tumor growth ${ }^{[2]}$. Subsequently, Escherichia coli-derived recombinant endostatin was shown to induce regression and prevent growth of experimental tumors in mice when administered in daily doses as high as $20 \mathrm{mg} / \mathrm{kg}^{[2,3]}$. A novel Escherichia coli derived rh-endostatin was developed by MedGen Ltd (Yantai City, China). Compared with the rh-endostatin reported in the literature, an additional nine-amino acid-sequence (MGGSHHHHH) was added at the N-terminal of the protein, which resulted in the formation of a six-histidine tag (His-tag). The His-tag can be chelated with metal ions such as $\mathrm{Ni}^{2+}$ with a relatively high affinity, so it was utilized to simplify purification and to improve stability of the protein. The present study attempted to reveal the pharmacokinetics and the possibility of accumulation after single or multiple doses of this novel rh-endostatin in Rhesus monkeys.

\section{Materials and methods}

Drugs and reagents The rh-endostatin used in this study was provided by MedGen (lot YH0502, purity $>98 \%$ ). The drug was dissolved in $5 \mathrm{mmol} / \mathrm{L}$ Tris $\cdot \mathrm{HCl}(\mathrm{pH}$ 7.2) and stored at $4{ }^{\circ} \mathrm{C}$ before use. 
The ACCUCYTE ${ }^{\circledR}$ Human Endostatin ${ }^{\mathrm{TM}}$ enzyme immunoassay (EIA) kit was purchased from CytImmune Sciences Inc (lot 5AE002-SA, Maryland, USA). All other reagents were purchased from commercial sources and were of analytical grade.

Animals Rhesus monkeys (weighing $5.3 \mathrm{~kg} \pm 0.8 \mathrm{~kg}$, Grade I, Certificate BDW95002) were provided by the Animal Raising Center of the Academy of Military Medical Sciences, China. The animals were individually housed in stainlesssteel cages and fed with a standard monkey diet. Fresh fruit was provided twice per day and water was available $a d$ libitum.

Experimental design Three iv groups (at a dose rate of $1.5,4.5$, and $13.5 \mathrm{mg} / \mathrm{kg}$ body weight, respectively) were assigned to a $3 \times 3$ crossover design to perform an auto-control experiment, in which each animal received the three doses mentioned above, with an interval of $7 \mathrm{~d}$ between doses (washing out period). Three animals in the sc group were administered rh-endostatin at the dose rate of $1.5 \mathrm{mg} / \mathrm{kg}$. Finally, a multiple-dose group comprising three animals was also designed, in which the monkeys received seven consecutive iv injections of rh-endostatin at the dose rate of 1.5 $\mathrm{mg} / \mathrm{kg}$, once per day.

Sample collection and assay Whole blood samples were drawn from the femoral veins of the animals using a puncture needle immediately before administration and at 2, 10 min in the iv group and 20, $40 \mathrm{~min}, 1,1.5 \mathrm{~h}$ in the sc group, then at $2,4,8,12,24,36,48$, and $72 \mathrm{~h}$ in all groups after a single dose and the 1st and the 7th dose in the multiple-dose group. In the multiple-dose group, samples were also collected at $2 \mathrm{~min}$ and $24 \mathrm{~h}$ after the 4 th dose. The blood was kept undisturbed at room temperature, then centrifuged at $3000 \times \mathrm{g}$ for $10 \mathrm{~min}$. The serum was separated and stored at $-20^{\circ} \mathrm{C}$ untill the assay.

The EIA kit was utilized to determine the rh-endostatin levels in the serum samples. The assay was performed according to the guidance of the procedure specified by the manufacturer. A series of calibration standards provided by Medgen was set up in each microplate. The rh-endostatin levels in the unknown samples were obtained by being calculated from the Medgen calibration standard curves on the same microplate.

Data analysis The concentration-absorbance curves were drawn with the MicroCal Origin software (ver 5.0), and then the experimental data were fitted by Logistic function according to the following formula:

$$
Y=\frac{\left(E_{\max }-E_{\min }\right)}{\left(1+\left(X / \mathrm{EC}_{50}\right)^{\mathrm{Slope}}\right)}+E_{\min }
$$

In which, " $X$ " represents rh-endostatin concentration in samples, " $Y$ ' represents the absorbance at $492 \mathrm{~nm}$. The $E_{\max }$ and $E_{\min }$ were the maximal and the minimal absorbance, respectively.

The pharmacokinetic parameters were obtained by the computer program 3p97. Statistical inference was obtained by means of Student's $t$ test or Chi-square test.

\section{Results}

Validity of the method for determination of rhendostatin in monkey serum The ACCUCYTE ${ }^{\circledR}$ Human Endostatin $^{\mathrm{TM}}$ kit has been developed using rh-endostatin as the antigen for polyclonal antibody production, and is used in the kit as the assay standard. Studies have demonstrated that it has no cross-reactivity against a variety of cytokines and growth factors, including heat inactivated rh-endostatin and mouse endostatin.

Within the concentration range of $7.8-8000 \mu \mathrm{g} / \mathrm{L}$, the concentration-absorbance behavior of the rh-endostatin standard provided by Medgen is presented as an inhibitory sigmoid curve that could be described by 4 parameter logistic fitting. Maximal coefficients of variation (CV\%) of intraassay and inter-assay were $13.7 \%$ and $20.8 \%$, respectively. The limit of quantitation (LOQ) was $125 \mu \mathrm{g} / \mathrm{L}$ (with CV\% of $6.1 \%$ ). The average endogenous endostatin level observed in the rhesus monkey was $375 \pm 175 \mu \mathrm{g} / \mathrm{L}(n=12)$.

The results of the blank serum samples fortified with 2000, 500, and $125 \mu \mathrm{g} / \mathrm{L}$ tested rh-endostatin showed that the recovery rates were $87 \% \pm 5 \%(81 \%-91 \%), 93 \% \pm 18 \%$ (79\%-114\%), and 94\% $\pm 4 \%(90 \%-99 \%)$, respectively $(n=5$ parallel experiments). The $\mathrm{CV} \%$ of the intra-assay was less than $11.5 \%$, and the $\mathrm{CV} \%$ of the inter-assay was higher (as high as $19.7 \%$ ), so it is important to calculate the rhendostatin concentration in samples by the parameters obtained from the standard curve of the same microplate.

The validity studies demonstrated that the ACCUCYTE ${ }^{\circledR}$ Human Endostatin ${ }^{\mathrm{TM}}$ kit was reliable for the determination of serum endostatin levels. The specificity, sensitivity, accuracy, and precision all met the requirements for pharmacokinetics (PK) study.

Concentration-time curves and PK following single dose of rh-endostatin Serum concentration-time profiles of rh-endostatin following iv bolus injections at doses of $1.5,4.5$, and $13.5 \mathrm{mg} / \mathrm{kg}$ were best fitted to a three-compartment open model (Figure 1). Rh-endostatin concentration in serum dramatically decreased after iv injection, with the initial half lives $\left(\lambda_{1}\right)$ of $0.027 \pm 0.016 \mathrm{~h}, 0.04 \pm 0.03 \mathrm{~h}$, and $0.10 \pm 0.04 \mathrm{~h}(P<0.05 \mathrm{vs}$ the other two groups $)$ following iv 


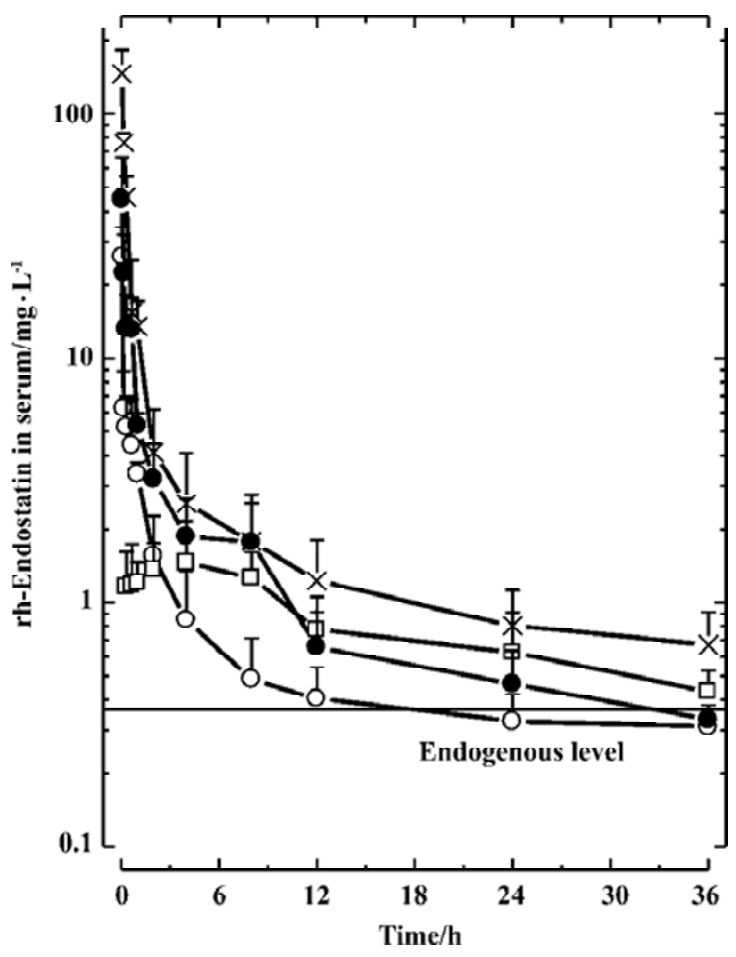

Figure 1. Concentration-time curves of rh-endostatin after a single iv and sc injection in rhesus monkeys. $\bigcirc$, iv $1.5 \mathrm{mg} / \mathrm{kg}$; $\bigcirc$, iv $4.5 \mathrm{mg} / \mathrm{kg}$; $\times$, iv $13.5 \mathrm{mg} / \mathrm{kg} ; \square$, sc $1.5 \mathrm{mg} / \mathrm{kg}$. The endogenous endostatin level set at $375 \pm 175 \mu \mathrm{g} / \mathrm{L}$.

injection of $1.5,4.5$, and $13.5 \mathrm{mg} / \mathrm{kg}$, respectively. The halflives of the terminal elimination phase $\left(\lambda_{3}\right)$ were $8 \pm 8 \mathrm{~h}, 3.1 \pm 1.4$ $\mathrm{h}$, and $20 \pm 14 \mathrm{~h}$, respectively. At a high dose rate of $13.5 \mathrm{mg} / \mathrm{kg}$, the value of $\lambda_{3}$ was obviously prolonged but without any statistically significant differences. Increased with dose, the mean areas under the serum concentration-time curve $\left[\mathrm{AUC}_{(0-\infty)}\right]$ of the three iv groups were $15 \pm 5 \mathrm{mg} \cdot \mathrm{h} \cdot \mathrm{L}^{-1}, 33 \pm 7$ $\mathrm{mg} \cdot \mathrm{h} \cdot \mathrm{L}^{-1}$ and $93 \pm 25 \mathrm{mg} \cdot \mathrm{h} \cdot \mathrm{L}^{-1}$, respectively. With a dose ratio of $1: 3: 9$, the ratio of $\mathrm{AUC}_{(0-\infty)}$ in the groups was 1:2.2:6.1.

Despite the increase in $\mathrm{AUC}_{(0-\infty)}$, the systemic clearances $\left(\mathrm{Cl}_{\mathrm{s}}\right)$ among the iv groups were not significantly different (Table 1), indicating that the pharmacokinetic behavior of endostatin within the examined dose range is of linear profile.

The concentration-time profiles following sc administration at a dose rate of $1.5 \mathrm{mg} / \mathrm{kg}$ can be described approximately by a two-compartment model (Figure 1). After injection, rh-endostatin was absorbed rapidly, with the time to peak $\left(T_{\max }\right)$ of $1.1 \pm 0.8 \mathrm{~h}$. The mean peak serum concentration $\left(C_{\max }\right)$ and $\mathrm{AUC}_{(0-\infty)}$ were $1.3 \pm 0.4 \mathrm{mg} / \mathrm{L}$ and $11 \pm 4$ $\mathrm{mg} \cdot \mathrm{h} \cdot \mathrm{L}^{-1}$, respectively. The terminal half-life $\left(T_{1 / 2 \beta}\right)$ was $8 \pm 3$ h. Compared with the iv group at the same dose, rh-endostatin had a relatively high bioavailability (F) of $70 \%$ after sc administration (Table 1).

PK after multiple dosing Following repeated iv administration of rh-endostatin for a 7-d period (once daily) at a dose rate of $1.5 \mathrm{mg} / \mathrm{kg}$, most of the rh-endostatin concentrations at the same time points following injection at $\mathrm{d} 1$ and $\mathrm{d} 7$ were with statistically significant difference (Figure 2 ). The trough level increased from $388 \pm 61 \mu \mathrm{g} / \mathrm{L}(\mathrm{d} \mathrm{1})$ to $623 \pm 261 \mu \mathrm{g} / \mathrm{L}(\mathrm{d} 4)$ and $1008 \pm 892 \mu \mathrm{g} / \mathrm{L}(\mathrm{d} 7)$, and the $\mathrm{AUC}_{(0-24 \mathrm{~h})}$ also increased from $22 \pm 13 \mathrm{mg} \cdot \mathrm{h} \cdot \mathrm{L}^{-1}(\mathrm{~d} 1)$ to $50 \pm 29$ $\mathrm{mg} \cdot \mathrm{h} \cdot \mathrm{L}^{-1}(\mathrm{~d} 7)$, but the difference was not significant $(P=$ 0.053). The calculated accumulation factor $\left(\mathrm{AUC}_{\mathrm{d} 7} / \mathrm{AUC}_{\mathrm{d} 1}\right)$

Table 1. Pharmacokinetic parameters of the rh-endostatin after iv and sc injection in rhesus monkeys. $n=3$. Mean \pm SD. ${ }^{b} P<0.05,{ }^{\mathrm{f}} P<0.001 v s$ the iv $1.5 \mathrm{mg} / \mathrm{kg}$ group.

\begin{tabular}{|c|c|c|c|c|}
\hline \multirow[t]{2}{*}{ Parameters } & \multicolumn{3}{|c|}{ iv } & \multirow{2}{*}{$\begin{array}{c}\mathrm{sc} \\
1.5 \mathrm{mg} / \mathrm{kg}\end{array}$} \\
\hline & $1.5 \mathrm{mg} / \mathrm{kg}$ & $4.5 \mathrm{mg} / \mathrm{kg}$ & $13.5 \mathrm{mg} / \mathrm{kg}$ & \\
\hline$V_{\mathrm{C}} / \mathrm{L} \cdot \mathrm{kg}^{-1}$ & $0.030 \pm 0.019$ & $0.08 \pm 0.04$ & $0.078 \pm 0.019^{\mathrm{f}}$ & $1.3 \pm 0.4^{\mathrm{f}}$ \\
\hline$T_{1 / 2 \mathrm{ka}} / \mathrm{h}$ & - & - & - & $0.34 \pm 0.14$ \\
\hline$T_{1 / 2 \lambda 1} / \mathrm{h}$ & $0.027 \pm 0.016$ & $0.04 \pm 0.03$ & $0.10 \pm 0.04^{\mathrm{b}}$ & - \\
\hline$T_{1 / 2 \lambda 2} / \mathrm{h}$ & $0.80 \pm 0.28$ & $0.5 \pm 0.4$ & $0.8 \pm 0.5$ & $1.9 \pm 2.0$ \\
\hline$T_{1 / 2 \lambda 3} / \mathrm{h}$ & $8 \pm 8$ & $3.1 \pm 1.4$ & $20 \pm 14$ & $8 \pm 3$ \\
\hline$T_{\max } / \mathrm{h}$ & - & - & - & $1.1 \pm 0.8$ \\
\hline$C_{\max } / \mathrm{mg} \cdot \mathrm{L}^{-1}$ & - & - & - & $1.3 \pm 0.4$ \\
\hline $\mathrm{AUC}_{0-\infty} / \mathrm{mg} \cdot \mathrm{h} \cdot \mathrm{L}^{-1}$ & $15 \pm 5$ & $33 \pm 7^{b}$ & $93 \pm 25^{\mathrm{b}}$ & $11 \pm 4$ \\
\hline $\mathrm{MRT}_{0-\infty} / \mathrm{h}$ & $3.6 \pm 0.9$ & $2.7 \pm 1.5$ & $9.2 \pm 2.3^{b}$ & $9.3 \pm 1.7$ \\
\hline $\mathrm{CL}_{\mathrm{S}} / \mathrm{L} \cdot \mathrm{h}^{-1} \cdot \mathrm{kg}^{-1}$ & $0.11 \pm 0.03$ & $0.046 \pm 0.010$ & $0.017 \pm 0.004$ & $0.15 \pm 0.05$ \\
\hline$V_{\mathrm{SS}} / \mathrm{L} \cdot \mathrm{kg}^{-1}$ & $0.39 \pm 0.22$ & $0.12 \pm 0.04$ & $0.148 \pm 0.013$ & $1.4 \pm 0.6$ \\
\hline F \% & - & - & - & $70 \pm 3$ \\
\hline
\end{tabular}




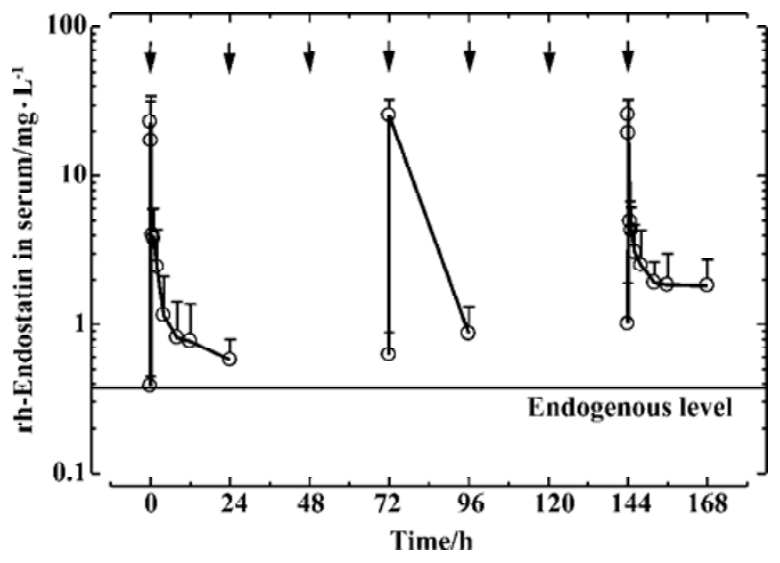

Figure 2. Concentration-time data of rh-endostatin after consecutive iv injection (q.d.×7) at a dose of $1.5 \mathrm{mg} / \mathrm{kg}$ in Rhesus monkeys. The endogenous endostatin levels set at $375 \pm 175 \mu \mathrm{g} / \mathrm{L}$.

was $2.3 \pm 0.6(P=0.012)$, indicating that the rh-endostatin had a tendency to accumulate in the body after successive iv administrations over $7 \mathrm{~d}$ with an interval of $24 \mathrm{~h}$ between doses.

\section{Discussion}

Folkman et al firstly descrbied the angiogenesis inhibitor endostatin in January $1997^{[2]}$. Although the molecular mechanisms behind the inhibition of angiogenesis have not yet been elucidated, endostatin seemed to inhibit endothelial cell migration in vitro and appeared to be highly effective in murine in vivo studies ${ }^{[4]}$. Endostatin thought to be an ideal anticancer weapon, was quickly pushed into clinical trials ${ }^{[5-8]}$. Thus far, however, recombinant endostatin prepared from Escherichia coli is insoluble after purification and therefore inappropriate for clinical settings. A soluble form of endostatin is available from a yeast system that has a relatively low yield and high cost, which has made it difficult to produce endostatin in quantities sufficient for extensive clinical evaluation ${ }^{[9]}$.

Researches attempted to solve the problems mentioned above, including using the His-tag technique ${ }^{[10-12]}$. The rhendostatin used in this study was His-tagged, containing a six-histidine residue sequence and an affinity tag at its $\mathrm{N}$ terminal, so it could be effectively extracted by affinity chromatography based on immobilized metal ions such as $\mathrm{Ni}^{2+}$. In this capture step, we were able to purify $100 \%$ of the recombinant protein with more than $99 \%$ purity just as reported previously ${ }^{[13]}$. The in vivo antiangiogenic and anticancer activities of this His-tag recombinant endostatin are as potent as those of the previously reported soluble form. Further, His-tag endostatin is also more convenient for analysis. In our study, we utilized a rapid and sensitive approach, Matrix-Assisted Laser Desorption Ionization-Time of FlightMass Spectrometry (MALDI-TOF-MS), to analyze the proteins, which provided highly accurate the molecular weight information about the protein (data not shown).

There was a relatively high basic endostatin level in monkeys ( $375 \pm 175 \mu \mathrm{g} / \mathrm{L})$, and it was consistent with endostatin being an endogenous protein. Moreover, to obtain an effect on tumors, the dose of endostatin in precilinical experiments and the recommended dose used in clinical trials are much higher than the dose required of most other therapeutical proteins, which reached the level of $\mathrm{mg} / \mathrm{kg}$ (or $\mathrm{mg}$ / $\mathrm{m}^{2}$ ). Our PK studies showed that, although statistically not significant, $\lambda_{3}$ of the high dose group was obviously prolonged, suggesting that an exorbitant dose might affect the clearance of endostatin in the body. The results of the multiple dose study for $7 \mathrm{~d}$ continuously at the dose level of $1.5 \mathrm{mg} / \mathrm{kg}$ also suggested that rh-endostatin tended to accumulate in the body with a statistically significant accumulation factor of 2.3. Some clinical trials have shown that endostatin may cause side effects in the cardiovascular system, especially a dose-dependent toxicity in the heart. So it is best to avoid over accumulation of endostatin in the body by regulating the intervals between each administration. Furthermore, the PK study shows that differences between individuals are great, so individual monitoring during the course of treatment is also recommended in clinical trials.

\section{Acknowledgment}

The study was financially supported partly by MedGen Ltd (Yantai City, Shandong Province, China).

\section{References}

1 Sasaki T, Fukai N, Mann K, Gohring W, Olsen BR, Timpl R. Structure, function and tissue forms of the C-terminal globular domain of collagen XVIII containing the angiogenesis inhibitor endostatin. EMBO J 1998; 17: 4249-56.

2 O'Reilly MS, Boehm T, Shing Y, Fukai N, Vasios G, Lane WS, et al. Endostatin: an endogenous inhibitor of angiogenesis and tumor growth. Cell 1997; 88: 277-85.

3 Beohm T, Folkman J, Browder T, O’Reilly MS. Antiangiogenic therapy of experimental cancer does not induce acquired drug resistance. Nature 1997; 390: 404-7.

4 Zatterstrom UK, Felbor U, Fukai N, Olsen BR. Collagen XVIII/ endostatin structure and functional role in angiogenesis. Cell Struct Funct 2000; 25: 97-101.

5 Iughetti P, Suzuki O, Godoi PH, Alves VA, Sertie AL, Zorick T, et al. A polymorphism in endostatin, an angiogenesis inhibitor, predisposes for the development of prostatic adenocarcinoma. Cancer Res 2001; 61: 7375-8.

6 Maio M, Altomonte M, Calabro L, Fonsatti E. Bioimmunotherapeutic 
targets on angiogenetic blood vessels in solid malignangies. Front Biosci 2001; 6: D776-84.

7 Ryan CJ, Wilding G. Angiogenesis inhibitors. New agents in cancer therapy. Drugs Aging 2000; 17: 249-55.

8 Mundhenke C, Thomas JP, Wilding G, Lee FT, Kelzc F, Chappell R, et al. Tissue examination to monitor antiangiogenic therapy: a phase I clinical trial with endostatin. Clin Cancer Res 2001; 7: 3366-74.

9 Huang X, Wong MK, Zhao Q, Zhu Z, Wang KZ, Huang N, et al. Soluble recombinant endostatin purified from Escherichia coli: antiangiogenic activity and antitumor effect. Cancer Res 2001; 61: $478-81$.

10 Hengen P. Purification of His-Tag fusion proteins from Escherichia coli. Trends Biochem Sci 1995; 20: 285-6.
11 Tallet B, Astier-Gin T, Castroviejo M, Santarelli X. One-step chromatographic purification procedure of a His-tag recombinant carboxyl half part of the HTLV-I surface envelope glycoprotein overexpressed in Escherichia coli as a secreted form. J Chromatogr B Biomed Sci Appl 2001; 753: 17-22.

12 Gibert S, Bakalara N, Santarelli X. Three-step chromatographic purification procedure for the production of a his-tag recombinant kinesin overexpressed in E. coli. J Chromatogr B Biomed Sci Appl 2000; 737: $143-50$

13 Huang YW, Lu ML, Qi H, Lin SX. Membrane-bound human 3betahydroxysteroid dehydrogenase: overexpression with His-tag using a baculovirus system and single-step purification. Protein Expr Purif 2000; 18: 169-74.

\title{
The 69th Annual Scientific Meeting of the Japanese Circulation Society
}

\author{
2005 Mar 19-21 Pacifico Yokohama, Japan
}

\author{
Please contact \\ Tetsu YAMAGUCHI, Chairman, MD, PhD, \\ Toranomon Hospital \\ 2-2-2 Toranomon, Minato-ku, Tokyo 105-8470, Japan \\ Phn 81-3-3505-5872 Fax 81-3-3505-5873 \\ E-Mail jcs69@convention.co.jp \\ URL http://www2.convention.co.jp/jcs69/
}

